\title{
PATTERN RECOGNITION: MOTOR SKILLS DEVELOPMENT IN GIRLS AGED 15
}

\author{
Kapkan O.O. ${ }^{1}$, Khudolii O.M. ${ }^{2}$, Bartík P. ${ }^{3}$ \\ ${ }^{1}$ Donbas National Academy of Civil Engineering and Architecture \\ ${ }^{2}$ H.S. Skovoroda Kharkiv National Pedagogical University \\ ${ }^{3}$ Matej Bel University
}

Corresponding Author: Kapkan O.O., e-mail: ekapkan@gmail.com

Accepted for Publication: March 20, 2019

Published: March 25, 2019

DOI:10.17309/tmfv.2019.1.06

\begin{abstract}
The study objective is to determine physical exercises modes when developing motor skills in girls aged 15. Materials and methods. The participants in the study were 40 girls aged 15. To achieve the objectives set, the following research methods were used: study and analysis of scientific and methodological literature; pedagogical observation, timing of training tasks; pedagogical experiment, methods of mathematical statistics, methods of mathematical experiment planning, discriminant analysis. To achieve the objective set, the study examined the effect of different variants of performing exercises, specifically: the number of repetitions $\left(X_{1}\right)$ and rest intervals $\left(X_{2}\right)$ on mastering a press headstand technique. The girls aged 15 were divided into four groups according to the experiment plan. During the learning process, a method of algorithmic orders was used. The student could proceed to the next exercise only after a correct performance of the previous exercise on three consecutive attempts. The number of repetitions needed to teach exercises in each series of training tasks was recorded. The level of proficiency in the physical exercises performance was determined by the alternative method: "performed" or "failed". A technically correct performance of the exercise gave the students " 1 " point; a failure to perform the exercise gave them " 0 " entered in the protocol.

Results. The $2^{2}$ type experiment made it possible to study the multifactorial structure of teaching the girls aged 15, using a program of algorithmic orders; to specify optimal correlations of factors for their use when teaching physical exercises during physical education classes; to collect data for the calculation of regression models of teaching separate series of training tasks and for discriminant analysis to obtain a generalized model of teaching an exercise in general.

Conclusions. To select a generalized mode of exercises of the series of tasks when teaching girls aged 15 a press headstand and handstand, the first discriminant function can be used with an emphasis on the most informative variables.

The regression equations obtained from the analysis of the $2^{2}$ full factorial experiment data make it possible to specify and select the most effective modes of exercises for mastering separate series of training tasks. Keywords: discriminant analysis, series of training tasks, programmed learning, girls.
\end{abstract}

\section{Introduction}

The analysis of scientific and methodological literature highlights the relevance of focusing attention on the study of regularities of motor skills development in children and adolescents (Wright, 1999; Khudolii \& Ivashchenko, 2014; Ivashchenko, 2016). Rink, Jones, Kirby, Mitchell and Doutis (2007) state that the knowledge of regularities of motor skills development in children and adolescents is the basis of professional excellence of physical education teachers.

(C) Kapkan O.O., Khudolii O.M., Bartík P., 2019.
The research papers by Chernenko (2015), Ivashchenko, Iermakov, Khudolii, Yermakova, Cieślicka and Harkusha (2018), Ivashchenko (2017) ascertain that the repetition modes of exercises during motor skills development significantly influence training effectiveness. According to Samuel, Zavdy, Levav, Reuveny, Katz and Dubnov-Raz (2017), Balaban (2018), physical activity can both positively and negatively affect children's cognitive activity and their motor skills development. A regression analysis performed on the basis of a $2^{\mathrm{k}}$ type full factorial experiment data is an effective method for defining optimal modes of 
physical exercises during physical education classes (Ivashchenko, 2016).

In their research papers, Khudolii and Ivashchenko (2014), Lopatiev, Ivashchenko, Khudolii, Pjanylo, Chernenko and Yermakova (2017) substantiated the conceptual approaches to experiment planning when studying the effectiveness of learning process and to developing learning models. The researchers ascertained the effectiveness of using factorial plans for studying the process of teaching children and adolescents and developing regression models. The papers by Acher, Arca and Sanmarti (2007), Chatzipanteli, Digelidis, Karatzoglidis and Dean (2016) point to the importance of modeling process in children's cognitive activity. According to García-Moya, Moreno and Jiménez-
Iglesias (2012), Wang, Karns and Meredith (2003), the use of factorial experiment plans in the studies involving adolescents and children contributes to improving the quality of evaluation of their development indicators. The validity of using a $2^{\mathrm{k}}$ type full factorial experiment is confirmed by the data of Correa et.al. $(2009,2012)$.

During motor skills development, the important element is pedagogical control of motor abilities development and the dynamics of proficiency level in physical exercises (Khudolii \& Iermakov, 2011; Ivashchenko, 2016). Discriminant analysis is an effective method for assessing schoolchildren's condition. It allows to classify schoolchildren by the level of motor skills development (Cantell, Smyth \& Ahonen, 2003; Donovan, Mercier \& Phillips, 2015), as well as to

Table 1. Press headstand and handstand training program

\begin{tabular}{ccc}
\hline $\begin{array}{c}\text { Informative frame } \\
\text { (what is performed) }\end{array}$ & $\begin{array}{c}\text { Operational frame } \\
\text { (how it is performed) }\end{array}$ & $\begin{array}{c}\text { Control frame } \\
\text { (proceed to training the next exercise) }\end{array}$ \\
\hline
\end{tabular}

First series of training tasks - exercises for developing motor abilities

From stoop standing position, with the back Performed by jumping off both feet, hold If the student performs the exercise against stall bars, proceed to arch hang the position for 3-4 seconds correctly three times in a row, proceed to the next exercise

In prone position, bend arms and knees (5 Performed with maximum amplitude times in 5-6 seconds)

If the student performs the exercise for 5-6 seconds, proceed to the next exercise

Second series of training tasks - starting and ending positions

From squatting position, lean forward, put the Hold the position for 3-4 seconds head down on mat on the marking and evenly shift the body weight to the head and arms

If the student performs the exercise correctly three times in a row, proceed to the next exercise

Third series of training tasks - actions without which the exercise performance is impossible

From squatting position, return to starting Transition to headstand and handstand If the student performs the exercise position to perform a headstand and should be done by straightening the legs handstand. Straighten the legs, transition to a correctly three times in a row, proceed to the next exercise

headstand and handstand with bent legs

Fourth series of training tasks - teaching to control movement time and muscular effort

In kneeling position, bending and straightening of the arms (5 times)

Bending and straightening of the arms in stoop standing position (5 times)

From normal standing position, lean forward, touch the floor with the palms and, walking slowly on the hands, adopt a prone position and return to starting position in the same way

Fifth series of training tasks - separate parts of the target exercise and preliminary exercises

From squatting position, return to starting Straighten the back and hold balance with If the student performs the exercise position to perform a headstand and bent legs for 3-4 seconds handstand. Straighten the legs, transition to a headstand and handstand with bent legs

Perform a headstand and handstand, back and Focus on the exercise technique legs against the wall, with assistance

Sixth series of training tasks - performing the whole exercise

Perform a headstand and handstand, back and Hold the headstand and handstand for 3-4 If the student performs the exercise legs against the wall, without assistance seconds

Headstand and handstand without assistance Hold the headstand and handstand for 3-4 the next exercise

seconds correctly three times in a row, proceed to the next exercise

If the student performs the exercise correctly three times in a row, proceed to the next exercise third attempt 
determine the informative value of a test battery for assessing the impact of physical training on the basic motor competences (Herrmann, Gerlach \& Seelig, 2016; Ivashchenko, 2016).

However, physical exercises modes in mastering series of training tasks within programmed learning remain underexplored, the problem of control over schoolchildren's learning process needs further research.

The study objective is to determine physical exercises modes when developing motor skills in girls aged 15 .

\section{Materials and methods}

Study participants. The participants in the study were 40 girls aged 15 . The children and their parents were fully informed about all the features of the study and gave their consent to participate in the experiment.

Study organization. To achieve the objective set, the following research methods were used: study and analysis of scientific and methodological literature; pedagogical observation, timing of training tasks; pedagogical experiment, methods of mathematical statistics, methods of mathematical experiment planning, discriminant analysis.

The pedagogical experiment was conducted in the secondary school No. 22, Kramatorsk, Donetsk region, in the 2012-2013, 2013-2014 academic years.

During the learning process, the study used a method of algorithmic orders. The press headstand and handstand training program included training tasks given in Table 1 . The student could proceed to the next exercise only after a correct performance of the previous exercise on three consecutive attempts. The number of repetitions needed to teach exercises in each series of training tasks was recorded. The level of proficiency in the physical exercises performance was determined by the alternative method: "performed" or "failed". A technically correct performance of the exercise gave the students " 1 " point; a failure to perform the exercise gave them " 0 " entered in the protocol.

To achieve the objective set, the study examined the effect of different variants of performing exercises, specifically: the number of repetitions $\left(X_{1}\right)$ and rest intervals $\left(X_{2}\right)$ on mastering a press headstand technique. The girls aged 15 were divided into four groups according to the experiment plan. The differences between the groups in the lesson plan resulted from the factorial

Table 2. $2^{2}$ type factorial experiment plan experiment conditions presented in Table 2. The bottom and top levels of the factors were chosen based on the data provided by Khudolii and Ivashchenko (2014), Ivashchenko (2016), Chernenko (2015), and were limited to the lesson framework.

Statistical analysis. This paper used the methods of analyzing the results of mathematical experiment planning of a $2^{\mathrm{k}}$ type full factorial experiment (Khudolii \& Ivashchenko, 2014; Ivashchenko, 2016).

The study materials were processed by the IBM SPSS 20 statistical analysis software. In the process of discriminant analysis, the study created a prognostic model for group membership. This model develops a discriminant function (or, when there are more than two groups - a set of discriminant functions) in the form of a linear combination of predictor variables, ensuring the best division of groups. These functions are developed according to a set of observations, for which their group membership is known. These functions can continue to be used for new observations with known values of predictor variables and unknown group membership.

For each canonical discriminant function, the study calculated: eigenvalue, dispersion percentage, canonical correlation, Wilks' Lambda, Chi-square.

The study protocol was approved by the Ethical Committee of the University. In addition, the children and their parents or legal guardians were fully informed about all the features of the study, and a signed informedconsent document was obtained from all the parents.

\section{Study results}

Table 3 shows the results of analysis of $2^{2}$ type full factorial experiment data.

First series. Exercises for developing motor abilities. For the girls aged 15, the most influential factor is the number of repetitions $\left(X_{1}\right)$; the relationship between the number of repetitions and rest intervals $\left(X_{1} X_{2}\right)$ is less influential; the number of rest intervals $\left(X_{2}\right)$ has even less influence. To improve training effectiveness, it is necessary to increase the number of repetitions from 6 to 12 times and to increase rest intervals $\left(X_{2}\right)$ from 60 to 120 seconds. The girls aged 15 are most influenced by the first factor $\left(X_{1}\right)$, the percentage contribution is $39.8 \%$; the relationship between both factors $\left(X_{1} X_{2}\right)$, the percentage contribution is $37.5 \%$; and the second factor $\left(X_{2}\right)$, the percentage contribution is $22.6 \%$.

\begin{tabular}{ccc}
\hline \multirow{2}{*}{ Variants of exercises } & \multicolumn{3}{c}{ Modes of training } \\
\cline { 2 - 3 } & $\boldsymbol{X}_{1}$ (repetition number) & $\boldsymbol{X}_{2}$ (rest interval) \\
\hline 1 & $6-$ & $60-$ \\
2 & $12+$ & $60-$ \\
3 & $6-$ & $120+$ \\
4 & $12+$ & $120+$ \\
\hline
\end{tabular}


Table 3. Models of teaching the series of tasks "Press headstand and handstand" to the girls aged 15 ( $X_{1}-$ amount, $X_{2}-$ rest intervals, $X_{1} X_{2}$ - relationship between them)

\begin{tabular}{|c|c|c|c|c|}
\hline \multirow{2}{*}{ Series of training tasks } & \multirow{2}{*}{ Regression equations for natural variables } & \multicolumn{3}{|c|}{$\begin{array}{c}\text { Percentage contribution to } \\
\text { achievement of target indicator }\end{array}$} \\
\hline & & $X_{1}$ & $X_{2}$ & $X_{1} X_{2}$ \\
\hline $\begin{array}{l}\text { First series. Exercises for developing motor } \\
\text { abilities }\end{array}$ & $\mathrm{Y}=6.635+1.015 X_{1}+0.765 X_{2}+0.985 X_{1} X_{2}$ & 39.8 & 22.6 & 37.5 \\
\hline Second series. Starting and ending positions & $Y=12.825-1.475 X_{1}-1.377 X_{2}-2.575 X_{1} X_{2}$ & 20.3 & 17.6 & 61.9 \\
\hline $\begin{array}{l}\text { Third series. Actions without which the exer- } \\
\text { cise performance is impossible }\end{array}$ & $\mathrm{Y}=11.2-3 X_{1}-2 X_{2}-0.7 X_{1} X_{2}$ & 66.7 & 29.6 & 3.6 \\
\hline $\begin{array}{l}\text { Fourth series. Teaching to control movement } \\
\text { time and muscular effort }\end{array}$ & $\mathrm{Y}=7.65-0.35 X_{1}+0.4 X_{1} X_{2}$ & 37.9 & 12.4 & 49.6 \\
\hline $\begin{array}{l}\text { Fifth series. Separate parts of the target exer- } \\
\text { cise and preliminary exercises }\end{array}$ & $\mathrm{Y}=9.525-1.175 X_{1}-3.225 X_{2}$ & 11.3 & 85.8 & 2.7 \\
\hline Sixth series. Performing the whole exercise & $\mathrm{Y}=10.875+1.025 X_{1}-2.675 X_{1} X_{2}$ & 11.9 & 6.8 & 81.2 \\
\hline
\end{tabular}

Second series. Starting and ending positions. For the girls aged 15, the most influential factor is the relationship between the number of repetitions and rest intervals $\left(X_{1} X_{2}\right)$; the second most important factor is the number of repetitions $\left(X_{1}\right)$; rest intervals $\left(X_{2}\right)$ has the least influence. To improve training effectiveness, it is necessary to reduce the number of repetitions from 12 to 6 times and to reduce the rest interval from 120 to 60 seconds. The girls aged 15 are most influenced by the relationship between both factors $\left(X_{1} X_{2}\right)$, the percentage contribution is $61.9 \%$, as well as by the first factor $\left(X_{1}\right)$, the percentage contribution is $20.3 \%$, and the second factor $\left(X_{2}\right)$, the percentage contribution is $17.6 \%$.

Third series. Actions without which the exercise performance is impossible. For the girls aged 15, the most influential factor is the number of repetitions $\left(X_{1}\right)$; the less influential factor is the number of rest intervals $\left(X_{2}\right)$. The influence of the relationship between the number of repetitions and rest intervals $\left(X_{1} X_{2}\right)$ is insignificant. To improve training effectiveness, it is necessary to reduce the number of repetitions from 12 to 6 times and to reduce the rest interval from 120 to 60 seconds. The girls aged 15 are most influenced by the first factor $\left(X_{1}\right)$, the percentage contribution is 66.7 $\%$, as well as by the second factor $\left(X_{2}\right)$, the percentage contribution is $29.6 \%$, and the relationship between both factors $\left(X_{1} X_{2}\right)$, the percentage contribution is $3.6 \%$.

Fourth series. Teaching to control movement time and muscular effort. For the girls aged 15, the most influential factor is the relationship between the number of repetitions and rest intervals $\left(X_{1} X_{2}\right)$; the second most important factor is the number of repetitions $\left(X_{1}\right)$; the third one is the number of rest intervals $\left(X_{2}\right)$. To improve training effectiveness, it is necessary to increase the number of repetitions from 6 to 12 times and to increase rest intervals $\left(X_{2}\right)$ from 60 to 120 seconds. The girls aged 15 are most influenced by the relationship between both factors $\left(X_{1} X_{2}\right)$, the percentage contribution is $49.6 \%$, as well as by the first factor $\left(X_{1}\right)$, the percentage contribution is $37.9 \%$, and the second factor $\left(X_{2}\right)$, the percentage contribution is $12.4 \%$.

Fifth series. Separate parts of the target exercise and preliminary exercises. For the girls aged 15, the influential factors are the number of rest intervals $\left(X_{2}\right)$, the relationship between the number of repetitions and rest intervals $\left(X_{1} X_{2}\right)$, and the number of repetitions $\left(X_{1}\right)$. To improve training effectiveness, it is necessary to reduce the number of repetitions from 12 to 6 times and to reduce the rest interval from 120 to 60 seconds. The girls aged 15 are most influenced by the second factor $\left(X_{2}\right)$, the percentage contribution is $85.8 \%$, as well as by the relationship between both factors $\left(X_{1} X_{2}\right)$, the percentage contribution is $2.7 \%$, and the first factor $\left(X_{1}\right)$, the percentage contribution is $11.9 \%$.

Sixth series. Performing the whole exercise. For the girls aged 15, the most influential factor is the relationship between the number of repetition and rest intervals $\left(X_{1} X_{2}\right)$; the second most important factor is the number of repetitions $\left(X_{1}\right)$. The influence of the number of rest intervals $\left(X_{2}\right)$ is insignificant. To improve training effectiveness, it is necessary to reduce the number of repetition from 12 to 6 times and to reduce the rest interval from 120 to 60 seconds. The girls aged 15 are most influenced by the relationship between both factors $\left(X_{1} X_{2}\right)$, the percentage contribution is $81.2 \%$, as well as by the first factor $\left(X_{1}\right)$, the percentage contribution is $11.9 \%$, and the second factor $\left(X_{2}\right)$, the percentage contribution is $6.8 \%$.

To clarify the effect of different modes of physical exercises on the level of proficiency, the study conducted a discriminant analysis (see Table 4-10).

The first canonical function explains $67.0 \%$ of the variation in results, the second function $-27.9 \%$, the third one $-5.1 \%$, which indicates their high informativity $\left(r_{1}=0.961 ; r_{2}=0.914 ; r_{3}=.691\right)$ (see Table 4$)$. The materials of the canonical functions analysis show the statistical significance of the first, second, and third canonical functions $\left(\lambda_{1}=.007 ; p_{1}=0.001 ; \lambda_{2}=0.086 ; p_{2}\right.$ 
Table 4. Eigenvalues. Girls aged 15

\begin{tabular}{lcccc}
\hline Function & Eigenvalue & $\begin{array}{c}\text { \% of } \\
\text { Variance }\end{array}$ & $\begin{array}{c}\text { Cumulative } \\
\text { \% }\end{array}$ & $\begin{array}{c}\text { Canonical } \\
\text { correlation }\end{array}$ \\
\hline 1 & 12.156 & 67.0 & 67.0 & .961 \\
2 & 5.069 & 27.9 & 94.9 & .914 \\
3 & .916 & 5.1 & 100.0 & .691 \\
\hline
\end{tabular}

Table 5. Wilks' Lambda. Girls aged 15

\begin{tabular}{lcccc}
\hline $\begin{array}{c}\text { Test of } \\
\text { Function(s) }\end{array}$ & Wilks' Lambda & Chi-square & df & Sig. \\
\hline 1 through 3 & .007 & 171.036 & 18 & .000 \\
2 through 3 & .086 & 83.423 & 10 & .000 \\
3 & .522 & 22.113 & 4 & .000 \\
\hline
\end{tabular}

$\left.=0.001 ; \lambda_{3}=0.522 ; p_{2}=0.001\right)$. The first, second, and third functions have a high discriminative ability and value of interpretation with respect to the general totality (Table 5).

Table 6 presents standardized canonical discriminant function coefficients allowing to determine the ratio of variables' contribution to the function result. The number of repetitions for mastering the second, third, and fifth series of training tasks has the largest contribution to the first canonical function. The number of repetitions for mastering the fifth and sixth series of training tasks has the largest contribution to the second canonical function. The number of repetitions for mastering the fourth and fifth series of training tasks has the largest contribution to the third canonical function. This points to a differentiated influence of exersises modes on the effectiveness of teaching a press headstand and handstand.

Table 7 presents structure coefficients of the first canonical discriminant function, which are the coefficients of correlation between the variables and the function. The function is most substantially related to the results of mastering the third, fifth, and second series of training tasks: thus, a significant difference between modes of exercises 1-4 is observed in the number of repetitions needed to master the actions without which the exercise performance is impossible, starting and ending positions, and separate parts of the target exercise and preliminary exercises. The structure coefficients of the second canonical discriminant function show that the function is most substantially related to the results of mastering the sixth and second series of training tasks: thus, a significant difference between modes of exercises 2-4 is observed in the number of repetitions needed to master the starting and ending positions of the exercise and the whole exersise.

Table 8 shows the classification results of the groups, $95.0 \%$ of the original grouped observations were classified correctly. Therefore, the canonical discriminant function can be used to classify the modes of physical exercises during motor skills development.

Table 9 presents the centroid coordinates for the three groups. They make it possible to interpret the canonical function in relation to the classification role. The graphic material given in Fig. 1 shows the density of objects in each class and the distinct boundary between the classes. The most versatile mode of physical exercises for teaching the series of tasks is the first one.

\section{Discussion}

The paper assumed that a full factorial experiment and discriminant analysis would make it possible to determine the peculiarities of motor skills development in the girls aged 15. The study results show that in the suggested matrix of factorial experiment plan, the

Table 6. Standardized canonical discriminant function coefficients. Girls aged 15

\begin{tabular}{|c|c|c|c|}
\hline \multirow{2}{*}{ Series of training tasks } & \multicolumn{3}{|c|}{ Function } \\
\hline & 1 & 2 & 3 \\
\hline First series. Exercises for developing motor abilities & -.117 & .190 & -.065 \\
\hline Second series. Starting and ending positions & .759 & .521 & .003 \\
\hline Third series. Actions without which the exercise performance is impossible & .764 & .326 & .420 \\
\hline Fourth series. Teaching to control movement time and muscular effort & .055 & -.184 & .674 \\
\hline Fifth series. Separate parts of the target exercise and preliminary exercises & .521 & -.749 & -.589 \\
\hline Sixth series. Performing the whole exercise & -.280 & .900 & -.255 \\
\hline
\end{tabular}

Table 7. Structure matrix. Girls aged 15

\begin{tabular}{|c|c|c|c|}
\hline \multirow{2}{*}{ Series of training tasks } & \multicolumn{3}{|c|}{ Function } \\
\hline & 1 & 2 & 3 \\
\hline Third series. Actions without which the exercise performance is impossible & .532 & -.028 & .444 \\
\hline First series. Exercises for developing motor abilities & -.200 & -.126 & -.022 \\
\hline Sixth series. Performing the whole exercise & -.055 & .519 & -.410 \\
\hline Second series. Starting and ending positions & .441 & .478 & -.231 \\
\hline Fifth series. Separate parts of the target exercise and preliminary exercises & .422 & -.389 & -.596 \\
\hline Fourth series. Teaching to control movement time and muscular effort & -.005 & -.140 & .530 \\
\hline
\end{tabular}


Table 8. Classification resultsa

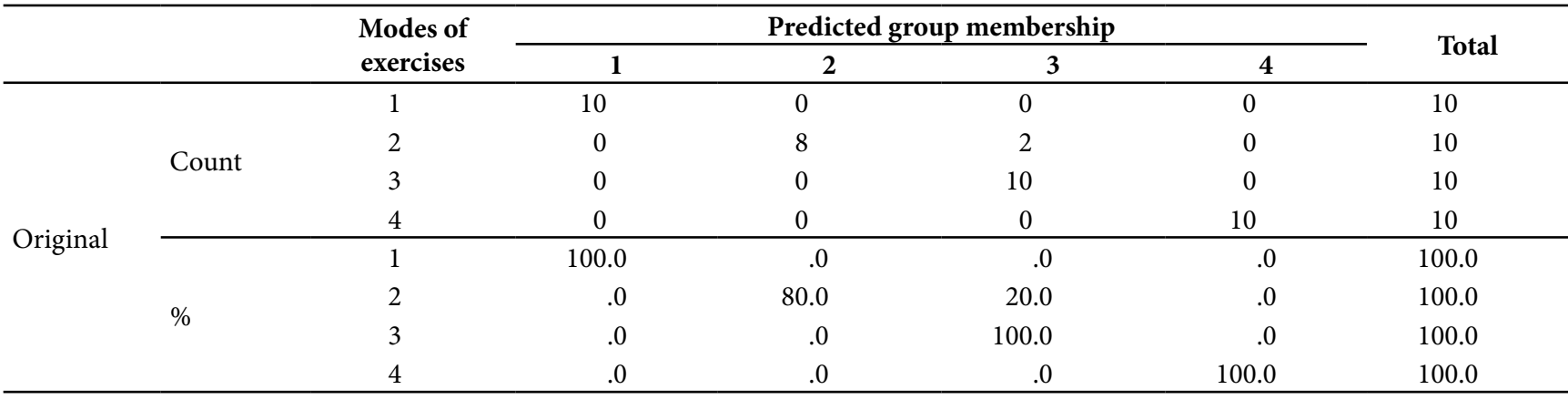

Table 9. Functions at group centroids. Unstandardized canonical discriminant functions evaluated at group means

\begin{tabular}{lccrrr}
\hline & \multicolumn{3}{c}{ Modes of training } & \multicolumn{3}{c}{ Function } \\
& $\boldsymbol{X}_{\mathbf{1}}$ (repetition number) & $\boldsymbol{X}_{\mathbf{2}}$ (rest interval) & $\mathbf{1}$ & $\mathbf{2}$ & $\mathbf{3}$ \\
\hline 1 & 6 & 60 & 3.548 & -2.797 & -333 \\
2 & 12 & 60 & 1.007 & 1.202 & -1.462 \\
3 & 6 & 120 & -867 & 2.761 & 1.020 \\
4 & 12 & 120 & -5.422 & -1.166 & .109 \\
\hline
\end{tabular}

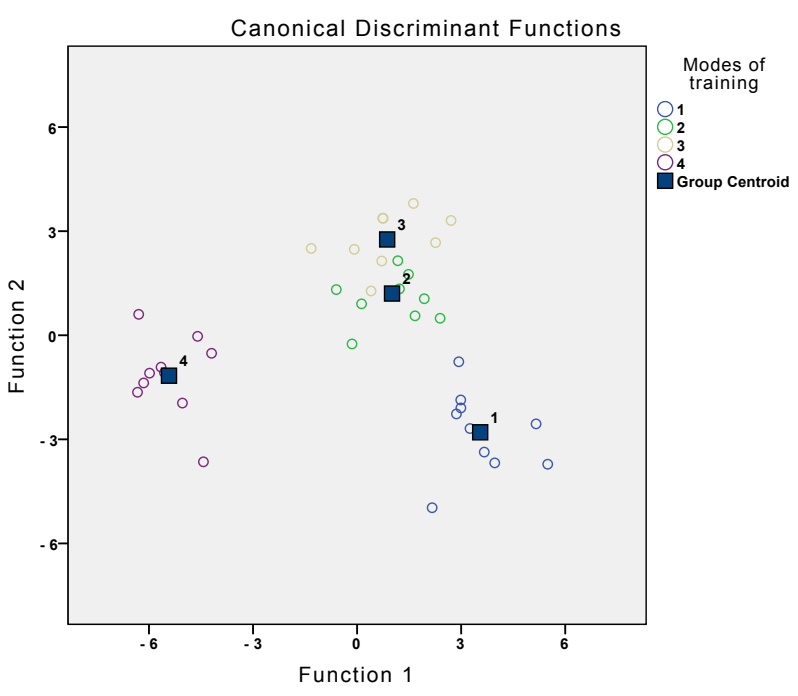

Fig. 1. Graphic representation of the classification results (modes of physical exercises 1-4)

chosen step of variation of factors is sufficient to study the influence of different physical exercises modes on the effectiveness of teaching a press headstand and handstand (Table 2).

The study makes an assumption on the possibility of using a discriminant function to evaluate the effectiveness of different physical exercises modes when teaching series of tasks. The verification of the canonical functions shows their statistical significance, and the discriminant function equation provides a possibility to select the best option for obtaining a positive effect when teaching the series of exercises (Table 10). The best option for teaching the girls aged 15 the headstand and handstand series of tasks is the first mode of physical exercises: 6 repetitions with a rest interval of 60 seconds.
The regression equations obtained from the analysis of the $2^{2}$ full factorial experiment data make it possible to specify and select the most effective modes of exercises for mastering separate series of training tasks (Table 3 ).

The study results supplement the data obtained by Khudolii and Ivashchenko (2014), Kapkan (2015), Ivashchenko (2016) on the effectiveness of using factorial experiment plans when studying the effectiveness of children and adolescents' learning process and on the reliability of obtained regression equations for modeling the process of motor skills development in schoolchildren. And the data of García-Moya, Moreno and Jiménez-Iglesias (2012), Wang, Karns and Meredith (2003) on the use of factorial experiments contributing to an objective study of "parent-child" relationships and the "motivation-behavior" process in children and adolescents.

The data obtained by Correa et.al. $(2009,2012)$ confirm the validity of using a $2^{\mathrm{k}}$ type full factorial experiment. The main purpose of plans is to neutralize the influence of unknown factors. The authors recommend using plans with three and four factors. The results of the above-mentioned studies (Table 3 ) show the effectiveness of using two factorial plans in the study of teaching motor actions.

The obtained results:

- specify the conceptual approaches to experiment planning when studying the effectiveness of learning process and developing learning models for children (Khudolii \& Iermakov, 2011; Ivashchenko, 2016), factorial experiment plans are objective tools for obtaining data for the calculation of regression models of teaching separate series of training tasks and for conducting discriminant analysis to obtain a generalized model of teaching the whole exersise; 
Table 10. Canonical discriminant function coefficients. Unstandardized coefficients

\begin{tabular}{|c|c|c|c|}
\hline \multirow{2}{*}{ Series of training tasks } & \multicolumn{3}{|c|}{ Function } \\
\hline & 1 & 2 & 3 \\
\hline First series. Exercises for developing motor abilities & -.052 & .084 & -.029 \\
\hline Second series. Starting and ending positions & .416 & .285 & .001 \\
\hline Third series. Actions without which the exercise performance is impossible & .376 & .160 & .207 \\
\hline Fourth series. Teaching to control movement time and muscular effort & .055 & -.184 & .672 \\
\hline Fifth series. Separate parts of the target exercise and preliminary exercises & .254 & -.365 & -.287 \\
\hline Sixth series. Performing the whole exercise & -.112 & .359 & -.102 \\
\hline (Constant) & -10.844 & -5.008 & -3.425 \\
\hline
\end{tabular}

- supplement the data on the use of a discriminant function for classifying schoolchildren by motor skills development (Cantell, Smyth \& Ahonen, 2003), and their attitude towards physical education and out-of-school physical activity (Donovan, Mercier \& Phillips, 2015); for organizing pedagogical control of schoolschildren's motor preparedness (Ivashchenko, 2016);

- confirm the data on the effectiveness of using a discriminant function when studying the effects of physical activity on motor skills development in children; when determining informative tests for pedagogical control in physical education (Ivashchenko, 2016; Herrmann, Gerlach \& Seelig, 2016).

The prospect for further exploration is to study the regularities of teaching physical exercises to boys aged $14-15$.

\section{Conclusions}

The $2^{2}$ type experiment made it possible to study the multifactorial structure of teaching the girls aged 15 , using a program of algorithmic orders; to specify the optimal correlations of factors for their use when teaching physical exercises during physical education classes; to collect data for the calculation of regression models of teaching separate series of training tasks and for conducting discriminant analysis to obtain a generalized model of teaching the whole exersise.

The discriminant analysis made it possible to determine physical exercises modes during motor skills development; to answer the question as to the significance of difference between the modes of training by the effectiveness of motor skills development; to define what motor tasks most substantially influence the differentiation of classes; what class the object belongs to based on the values of discriminant variables. The discriminant function structure coefficients show that the effectiveness of training program is determined by the selection of series of training tasks and modes of their performance.

To select a generalized mode of exercises of the series of tasks when teaching girls aged 15 a headstand and handstand, the first discriminant function can be used with an emphasis on the most informative variables.

The regression equations obtained from the analysis of the $2^{2}$ full factorial experiment data make it possible to specify and select the most effective modes of exercises for mastering separate series of training tasks.

\section{Acknowledgement}

The study was carried out in accordance with the research plan of the Ministry of Education and Science, Youth and Sports of Ukraine, within the topic 13.04 "Modeling of teaching and motor abilities development in children and adolescents" (2013-2014) (state registration number: 0113U002102).

\section{Conflict of interest}

The author declares no conflict of interests.

\section{References}

Khudolii, O.M., \& Ivashchenko, O.V. (2014). Simulation of the learning process and development of motor abilities in children and adolescents: Monograph. Kharkiv : OVS, 320. (in Ukrainian)

Lopatiev, A., Ivashchenko, O., Khudolii, O., Pjanylo, Y., Chernenko, S. \& Yermakova T. (2017). Systemic approach and mathematical modeling in physical education and sports. Journal of Physical Education and Sport (JPES), 17(1), suplement, 146-155. https://doi.org/10.7752/ jpes.2017.s1023

Ivashchenko, O., Iermakov, S., Khudolii, O., Yermakova, T., Cieślicka, M., \& Harkusha, S. (2018). Simulation of the regularities of physical exercises learning process of boys aged 8 years old. Pedagogics, Psychology, Medical-Biological Problems of Physical Training and Sports, 22(1), 11-16. https://doi.org/10.15561/18189172.2018.0102

Judith Rink, Laura Jones, Kym Kirby, Murray Mitchell, \& Panayiotis Doutis (2007). Teacher Perceptions of a Physical Education Statewide Assessment Program. Research Quarterly for Exercise and Sport, 78(3), 204-215. https://doi.org/10.1080/02701367.2007.10599418

Balaban, V. (2018). The relationship between objectively measured physical activity and fundamental motor skills in 8 to 11 years old children from the Czech Republic. Montenegrin Journal of Sports Science and Medicine, 7(2), 11-16. https://doi.org/10.26773/ mjssm. 180902 
Ivashchenko, O. (2017). Classification of 11-13 yrs girls' motor fitness, considering level of physical exercises' mastering. Pedagogics, Psychology, Medical-Biological Problems of Physical Training and Sports, 21(2), 65-70. https://doi.org/10.15561/18189172.2017.0203

Ivashchenko, O.V. (2016). Modelling of physical education students: Monograph. Kharkiv: OVS (in Ukrainian)

Acher, A., Arca, M., \& Sanmarti, N. (2007). Modeling as a teaching learning process for understanding materials: A case study in primary education. Science Education, 91(3), 398-418. https://doi.org/10.1002/sce.20196

Chatzipanteli, A., Digelidis, N., Karatzoglidis, C., \& Dean, R. (2016). A tactical-game approach and enhancement of metacognitive behaviour in elementary school students. Physical Education and Sport Pedagogy, 21(2),169-184. https:/doi.org/10.1080/17408989.2014.931366

Chernenko, S.O. (2015). Effectieness of junior form pupils' training of gymnastic exercises in different modes of their fulfillment. Pedagogics, Psychology, Medical-Biological Problems Of Physical Training And Sports, 19(8), 65-74. https://doi.org/10.15561/18189172.2015.0809

Correa, A. A., Grima, P., \& Tort-Martorell, X. (2009). Experimentation order with good properties for $2^{k}$ factorial designs. Journal of Applied Statistics, 36(7), 743754. https://doi.org/10.1080/02664760802499337

Correa, A. A., Grima, P., \& Tort-Martorell, X. (2012). Experimentation order in factorial designs: new findings. Journal of Applied Statistics, 39(7), 1577-1591. https://doi org/10.1080/02664763.2012.661706

García-Moya, I., Moreno, C., \& Jiménez-Iglesias, A. (2012). Building a composite factorial score for the assessment of quality of parent-child relationships in adolescence. European Journal of Developmental Psychology, 10(5), 642648. https://doi.org/10.1080/17405629.2012.707781

Kapkan, O.O. (2015). Features of 14-15 years' age boys' training to physical exercises. Pedagogics, Psychology, Medical-
Biological Problems Of Physical Training And Sports, 19(9), 26-32. https://doi.org/10.15561/18189172.2015.0904

Wang, A., Karns, J. T., \& Meredith, W. (2003). Motivation, Stress, Self-Control Ability, and Self-Control Behavior of Preschool Children in China. Journal of Research in Childhood Education, 17(2), 175-187. https://doi. org/10.1080/02568540309595008

Wright Steven (1999). A compatative view of teaching practice in Physical Education. International Sports Studies, 21(1), 55-68.

Samuel, R. D., Zavdy, O., Levav, M., Reuveny, R., Katz, U., \& Dubnov-Raz, G. (2017). The Effects of Maximal Intensity Exercise on Cognitive Performance in Children. Journal of Human Kinetics, 57(1), 85-96. https://doi.org/10.1515/ hukin-2017-0050

Khudolii, O. M., \& Iermakov, S. S. (2011). Regularities of the learning process of young gymnasts. Teoriâ ta Metodika Fizičnogo Vihovannâ, 0(5), 3-18, 35-41. (in Ukrainian) https://doi.org/10.17309/tmfv.2011.5.707

Cantell, M. H., Smyth, M. M., \& Ahonen, T. P. (2003). Two distinct pathways for developmental coordination disorder: Persistence and resolution. Human Movement Science, 22(4-5), 413-431. https://doi.org/10.1016/j. humov.2003.09.002

Donovan, C. B., Mercier, K., \& Phillips, S. R. (2015). Investigating Attitudes Toward Physical Education: Validation Across Two Instruments. Measurement in Physical Education and Exercise Science, 19(2), 91-98. https://doi.org/10.1080/1091367X.2015.1012511

Herrmann, C., Gerlach, E., \& Seelig, H. (2016). Basic motor competences in primary school. Rationale, assessment and empirical testing of a measurement instrument. German Journal of Exercise and Sport Research, 46(2), 60-73. https://doi.org/10.1007/s12662-015-0378-8

\title{
РОЗПІЗНАННЯ ОБРАЗІВ: ФОРМУВАННЯ РУХОВИХ НАВИЧОК У ДІВЧАТ 15 РОКІВ
}

\author{
Капкан О.О. ${ }^{1}$, Худолій О.М. ${ }^{2}$, Бартік П. ${ }^{3}$ \\ ${ }^{1}$ Донбаська національна академія будівництва і архітектури \\ ${ }^{2}$ Харківський національний педагогічний університет імені Г.С. Сковороди \\ ${ }^{3}$ Університет Матея Беля
}

Реферат. Стаття: 8 с., 10 табл., рис. 1, 21 джерело.

Мета дослідження - визначити режими виконання фізичних вправ у процесі формування рухових навичок у дівчат 15 років.

Матеріал і методи. У дослідженні прийняли 40 дівчат 15 років. Для вирішення поставлених завдань були використані методи дослідження: вивчення та аналіз науково-методичної літератури; педагогічне спостереження, хронометраж навчальних завдань; педагогічний експеримент, методи математичної ста- тистики, методи математичного планування експерименту, дискримінантний аналіз.

Результати. Експеримент типу $2^{2}$ надав змогу дослідити багатофакторну структуру процесу навчання дівчат 15 років за програмою алгоритмічних розпоряджень, уточнити оптимальні співвідношення факторів для їх використання у період навчання фізичних вправ під час уроків фізичної культури, отримати данні для розрахунку регресійних моделей навчання 
окремих серій навчальних завдань і проведення дискримінантного аналізу для отримання узагальненої моделі процесу навчання вправі в цілому.

Висновки. Для вибору узагальненого режиму виконання вправ серій завдань у процесі навчання стійці на голові і руках дівчат 15 років може бути використана перша дискримінантна функція з акцентом на найбільш інформативні змінні.
Рівняння регресіі, отримані в результаті аналізу даних ПФЕ $2^{2}$, дають можливість уточнити і вибрати найбільш ефективні варіанти режимів виконання вправ для оволодіння окремих серій навчальних завдань.

Ключові слова: дискримінантний аналіз, серії навчальних завдань, програмоване навчання, дівчата.

\title{
РАСПОЗНАВАНИЕ ОБРАЗОВ: РЕЖИМЫ ВЫПОЛНЕНИЯ ФИЗИЧЕСКИХ УПРАЖНЕНИЙ В ПРОЦЕССЕ ФОРМИРОВАНИЯ ДВИГАТЕЛЬНЫХ НАВЫКОВ У ДЕВУШЕК 15 ЛЕТ
}

\author{
Капкан Е.А. ${ }^{1}$, Худолей О.Н.․, Бартик П. ${ }^{3}$ \\ ${ }^{1}$ Донбасская национальная академия строительства и архитектуры \\ ${ }^{2}$ Харьковский национальный педагогический университет имени Г. С. Сковороды

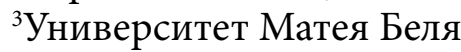

Реферат. Статья 8 с., 10 табл., Рис. 1, 21 источник.

Цель исследования - определить режимы выполнения физических упражнений в процессе формирования двигательных навыков у девушек 15 лет.

Материал и методы. В исследовании приняли 40 девушек 15 лет. Для решения поставленных задач были использованы методы исследования: изучение и анализ научно-методической литературы; педагогическое наблюдение, хронометраж учебных заданий; педагогический эксперимент, методы математической статистики, методы математического планирования эксперимента, дискриминантный анализ.

Результаты. Эксперимент типа $2^{2}$ предоставил возможность исследовать многофакторную структуру процесса обучения девушек 15 лет по программе алгоритмических предписаний, уточнить оптимальные соотношения факторов для их использования в период обучения физических упражнений на уроках физической культуры, получить данные для расчета регрессионных моделей обучения отдельных серий учебных заданий и проведения дискриминантного анализа для получения обобщенной модели процесса обучения упражнению в целом.

Выводы. Для выбора обобщенного режима выполнения упражнений серий заданий в процессе обучения стойке на голове и руках девушек 15 лет может быть использована первая дискриминантная функция с акцентом на наиболее информативные переменные.

Уравнения регрессии, полученные в результате анализа данных ПФЭ $2^{2}$ дают возможность уточнить и выбрать наиболее эффективные варианты режимов выполнения упражнений для овладения отдельных серий учебных заданий.

Ключевые слова: дискриминантный анализ, серии учебных заданий, программированное обучение, девушки.

\section{Information about the authors:}

Kapkan O.O.: ekapkan@gmail.com; http://org/0000-0003-4320-4276; Department of Physical Education Donbas National Academy of Civil Engineering and Architecture; Nebesnoi Sotni St, 14, Kramatorsk, 84333, Ukraine.

Khudolii O.M.: khudolii.oleg@gmail.com; http://orcid.org/0000-0002-5605-9939; Department of Theory and Methodology of Physical Education, Health and Medical Physical Culture, H. S. Skovoroda Kharkiv National Pedagogical University, Alchevskikh St, 29, Kharkiv, 61002, Ukraine.

Bartík P.: pavol.bartik@umb.sk; https://orcid.org/0000-0002-2087-7876; Department of Physical Education and Sports, Matej Bel University. Tajovského 40, 97401 Banská Bystrica, Slovakia.

Cite this article as: Kapkan, O.O., Khudolii, O.M., \& Bartík, P. (2019). Pattern Recognition: Motor Skills Development in Girls Aged 15. Teoriâ ta Metodika Fizičnogo Vihovannâ, 19(1), 44-52.

https://doi.org/10.17309/tmfv.2019.1.06

Received: 15.01.2019. Accepted: 20.03.2019. Published: 25.03.2019

This work is licensed under a Creative Commons Attribution 4.0 International License (http://creativecommons.org/ licenses/by/4.0). 